\title{
The Effectiveness of Pairwork Activities Technique on Writing Ability of Students in Vocational School
}

\author{
Hermi Zaswita and Rodiyal Ihsan \\ STKIP Muhammadiyah Sungai Penuh, Indonesia
}

\begin{abstract}
This study is aimed at finding out the effectiveness of pairwork activities technique on students' writing ability. The research is quasi-experiment with posttest only design. Students at grade XI Vocational School 1 Sungai Penuh engage in the study, whereas only two classes selected as sample (experimental class and control class). Writing test carries out after the treatment in each class, it means the instrument is constructed in writing form in order to know students ability in writing. The data are analyzed by using the t-test. The finding of hypotheses testing proves that the p-value is 0,00. Thus, the p-value is lower than 0,05 $(0,00<0,05)$ which means HO is rejected and $\mathrm{Hl}$ is accepted. Hence, the pairwork activities technique is effective to be used in creating student's better writing ability than conventional technique. Pairwork activities technique can enhance students activities in writing, where each pair of students should be active in generousing the ideas and cross-check their own writing with the intention to creating better writing outcome.
\end{abstract}

Keywords: Pairwork activities technique, Conventional technique, Writing ability, Quasi-experiment,Vocational school students

\section{INTRODUCTION}

Writing is one of the skills that ought to be held onby students in learning English. At the Vocational High School (SMK), students are targeted to attain the intermediate level in communicating verbally and in writing to interrelate in the context of daily life, the occupation world, and the business world. Nevertheless, writing in English is not easy for students, it entails a lot of practice, good vocabulary, and high-quality grammar. Students as wellfor a time find it difficult to convey their ideas into written form.

Concerning to the problem, learning which be ableto get better abilities and skillsof students in writing English needs to be applied and further researched in order to improve the process and results of learning to write. Studies in the context of learning using pairwork activities have been carried out by several researchers. In the experimental studies conducted by Suhartono (2013), Zohary 
(2014) and Ihsan (2016), for instance, it can be noticed that there is a significant effect of using pairwork activities to advance students' ability and skill in learning.Pairwork is one of the teaching techniques that attracts students to collaborate with colleagues. Students who are capable can assist their friends who have obscurity in writing. It makes the learning and teaching process more effective and efficient, because not only the teacher but also the students also play an active role in the learning process itself.

Furthermore, to find out the effectiveness of teaching techniques on students' writing abilities, the research has to be performed.The formulation of the problem in the study is:Does pairwork activities technique effective to be used to increating students' better writing ability than conventional technique? Therefore,the purpose of this study is to examine the effectiveness of pairwork activities on writing ability.

\section{LITERATURE REVIEW}

\section{Pairwork Activities Technique}

There are a number of experts who put forward theories about the pairwork activities technique. According to Harmer (1998: 206) pairwork is a good idea because it can directly enhance and encourage students to work together and can improve a better classroom climate. In other words, pairwork activities can assiststudents to discuss each other and exchange ideas. It is able to aid in making friends with each other in everyday life as well.

Bercikova (2007: 12) confess that pairwork is an appearance of interaction in the classroom where students work mutually by way of other students to check answers and labor on communicative activities. It is vastly upright in language learning mainly in writing. Students can split ideas collectively, arrange paragraphs and inspect each other's writing. McDonough (2004) adds that students who work in pairs are better than groups when contributing in foreign language learning. Teachers are also more effortless to manage students, consequently,they disburse more attention to the students. Nearby, by means of pairwork techniques, the teacher merely explains the subject theme for a short time, as a result students can afterwards better understand the lesson by practicing together with their partner mates.

Dealing with theories above, it can be assumed that the pairwork activities technique is able to be used in expanding students' ability in learning English, in terms of writing ability. Byutilizing this technique, students hold the opportunity to discuss and work mutually and practice their writing skills with friends in pair.

\section{Writing Ability}

Writing requires process and experience in order to gain writing ability. Students who have the ability to write are those who often practice writing activities, as a result they are able to create superior written text. As Brown (2004: $335)$ states that writing is the result of thoughts, concepts and procedures for 
improvement that require special expertise that does not develop naturally. With the same sense, Myles (2002: 1) says that writing ability is a complex process that engages the aptitude to communicate in written form and produce a text so as to convey an idea effectively.

Meanwhile in the context of a academic, writing ability is considered as an essential ability to obtain better results in continuingat higher level in learning. The reason is supported by Nation (2009: 111) and Peha (2004: 3 ) who argue that one of the goals of student learning is to obtain superior talent in writing. According to them this ability is very useful for students' careers going forward.Writing is an important skill to learn for field work and academic. In order to produce good written, text students must be able to encompass knowledge in writing. They have to organize ideas to make sentences, use punctuation and spelling correctly. They also have to organize writing into cohesive and coherent paragraphs and texts. That is why the ability to write assist them to find what they need in the future, especially when they are looking for work and other activities that require expertise in writing.

Hedge's opinion (2000: 302) can be a conclusion of all the opinions above. He said that the act of writing encompasses an assortment of activities: determiningthe purpose, expressing ideas, organizing information, selecting a language, drafting, reading and correcting. The opinion confirms that writing is a difficult activity. Moreover, it is can be drilled by students. Thus, writing ability is one process in which a person issues his/ ideas based on what is felt in his mind through writing.

\section{RESEARCH METHOD}

This study is a quasi-experimental research with post-test only design (without pre-test) because it compared the average (mean) of students' writing scores between the experimental class and the control class after the treatment. The experimental class was provided with treatment in the form of learning using the pairwork activities techniques. While the control class was given conventional learning techniques commonly used by teachers in the school. Both classes drawned on the same material, taught by the same instructor, and allocated with the same learning time.Two classes of grade XI Vocational School 1Sungai penuh were chosen as sample. Class XI Accounting 1 as an experimental class and Class XI Accounting 2 as a control class. The sample attained through purposive thesampling method by using this steps: (1) Collecting the average score of students writing on English writing subjects and (2) Two classes that have the same or nearly the same average value used as a sample class. The instrument applied in collecting data in this study was writing test in order to get data about students' writing ability. Afterwards, the data must be validated to the normality and homogeneity. Normality testing intended to see if the data obtained from research with normal distribution, analyze by using the Anderson Darling test with SPSS. Homogeneity testing strived to perceive whether the data from both samples which have homogeneous variance or not. In homogeneity testing used Ftest with SPSS.After the confirmation of normality and homogeneity of the data, the hypothesis testing was conducted. The hypothesis examined by t-test analysis 
in measuring the significance of the mean difference. The calculation was executedvia SPSS Version 20. The hypotheses in the study are as follow:

H1: Pairwork activities technique is effective to be used in creating better writing ability of students than theconventional technique.

H0: Pairwork activities is not effective to be used in creatingbetter writing ability of students than the conventional technique.

\section{FINDINGS AND DISCUSSION}

At the end of the research, students were assigned writing test. The writing test had been validated by expert judgement and ensure for the reliability since it was tried out before the use.Test intended to measure student's ability in writing after the treatment.In that case, students' scores were gained from the writing product. The result of students' writing ability data can be seen in the following table:

Table 1. Student Writing Ability in the Experiment Class and Control Class

\begin{tabular}{lcccccc}
\hline Class & N & $\begin{array}{c}\text { The } \\
\text { mean }\end{array}$ & StandardDeviation & Variance & $\begin{array}{c}\text { Maksimal } \\
\text { Score }\end{array}$ & $\begin{array}{c}\text { Minimal } \\
\text { Score }\end{array}$ \\
\hline Experimental & 16 & 82.5 & 7.6 & 57.3 & 96 & 72 \\
Control & 16 & 67.5 & 11.8 & 138.4 & 88 & 48 \\
\hline
\end{tabular}

In searching out the writing score, the score of the rubric of the score multiplied by 4 so that the highest score would be100. As of the table above it is identifed that there are 16 students in the experimental class. The highest score is 96 and the lowest score is 72 . The mean score of students is 82.5 with a variance of 57.3. In the control class, there are also 16 students. The highest score is 88 and the lowest score is 48 . The mean score of students is 67.5 with a variance of 138.4. This shows that there is a significant difference between students' writing ability in the experimental class and students in the control class. Then to test whether the students' writing ability data from the control class and the experimental class were normally distributed then Anderson Darling was tested using SPSS . Provided that if theP-value $>0.05$ then $\mathrm{HO}$ is accepted and if thePvalue $<0.05$ then $\mathrm{H} 0$ is rejected. The experimental class is normally distributed because the $\mathrm{P}$-value is $0,263, \mathrm{H} 0$ is accepted. As seen in the following figure: 


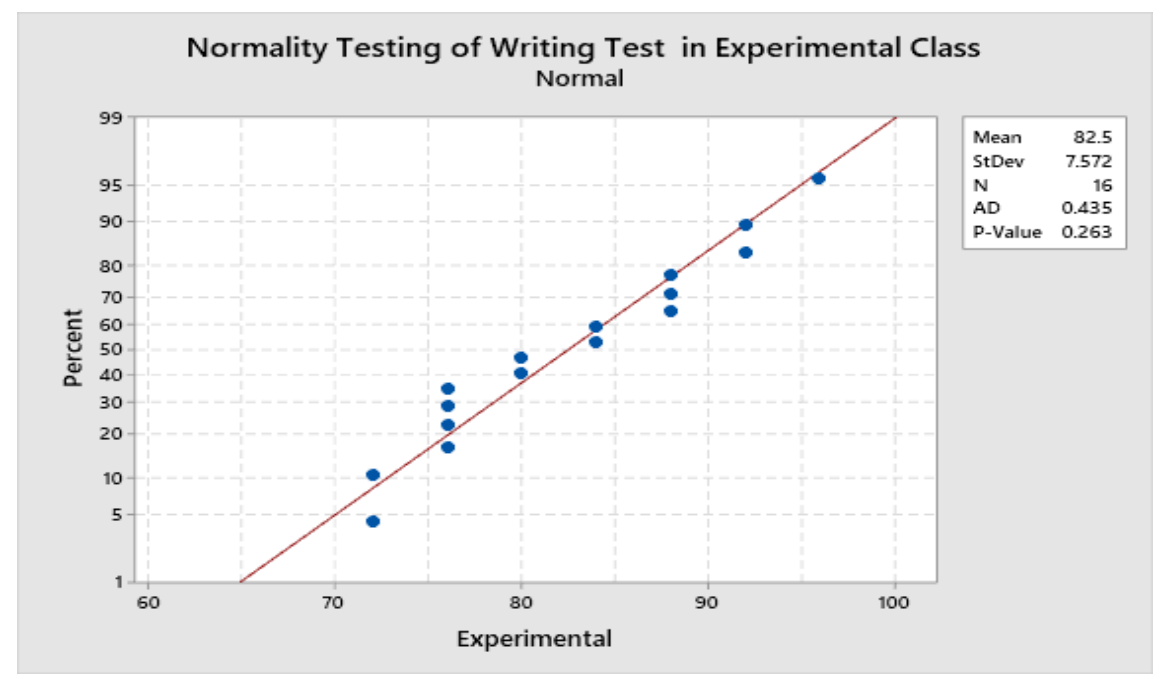

Figure 1. Normality Testing of Experimental Class

Writing ability of students from the control class is also normally distributed because a P-value is obtained at $0.847, \mathrm{H} 0$ is accepted. Like shown in the figure below:

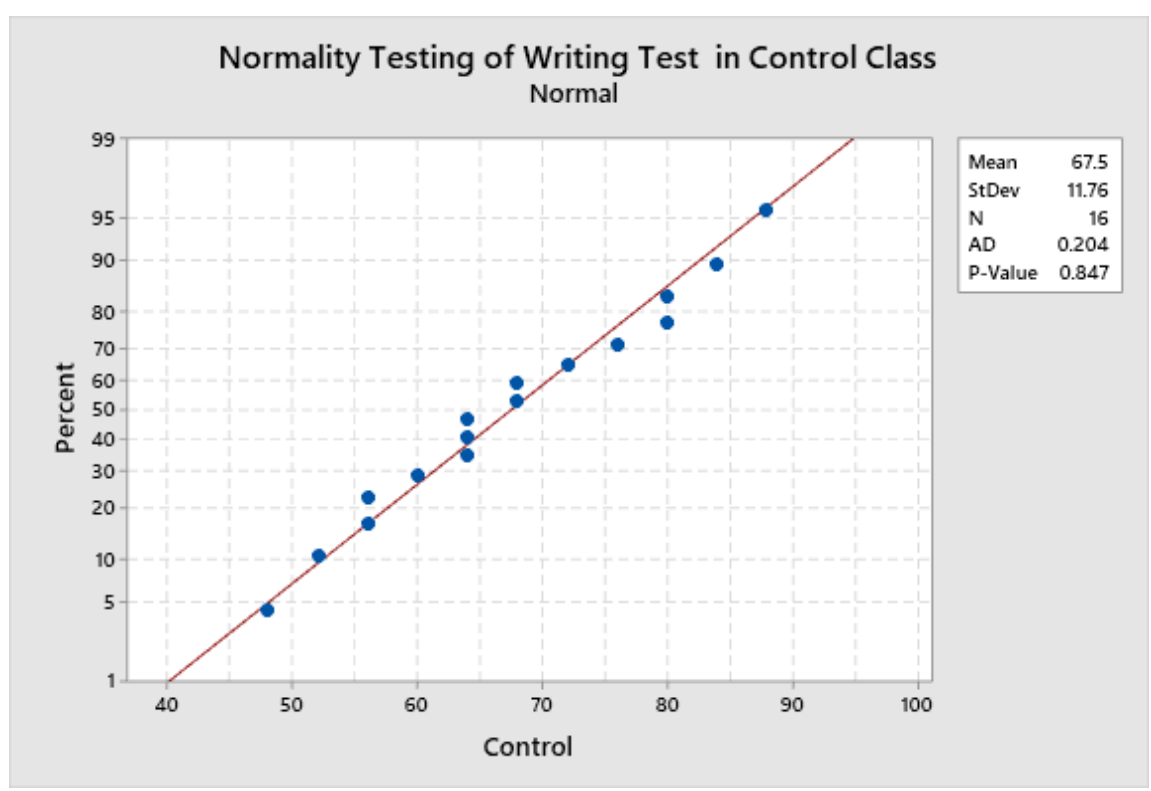

Figure 1. Normality Testing of Control Class

To find out whether the writing ability data of students from the control and experimental class is homogeneous, then the homogeneity of the data is tested using the F-Test via SPSS. Homogeneity test serves to find out that two or more groups of data are taken from populations that have the same variance. It provisions are by looking at the P-value $>0.05$ then both groups have the same or homogeneous. The results obtained by using the F-Test formula of 0.098 so that both class groups are declared homogeneous.Can be seen in the following figure: 


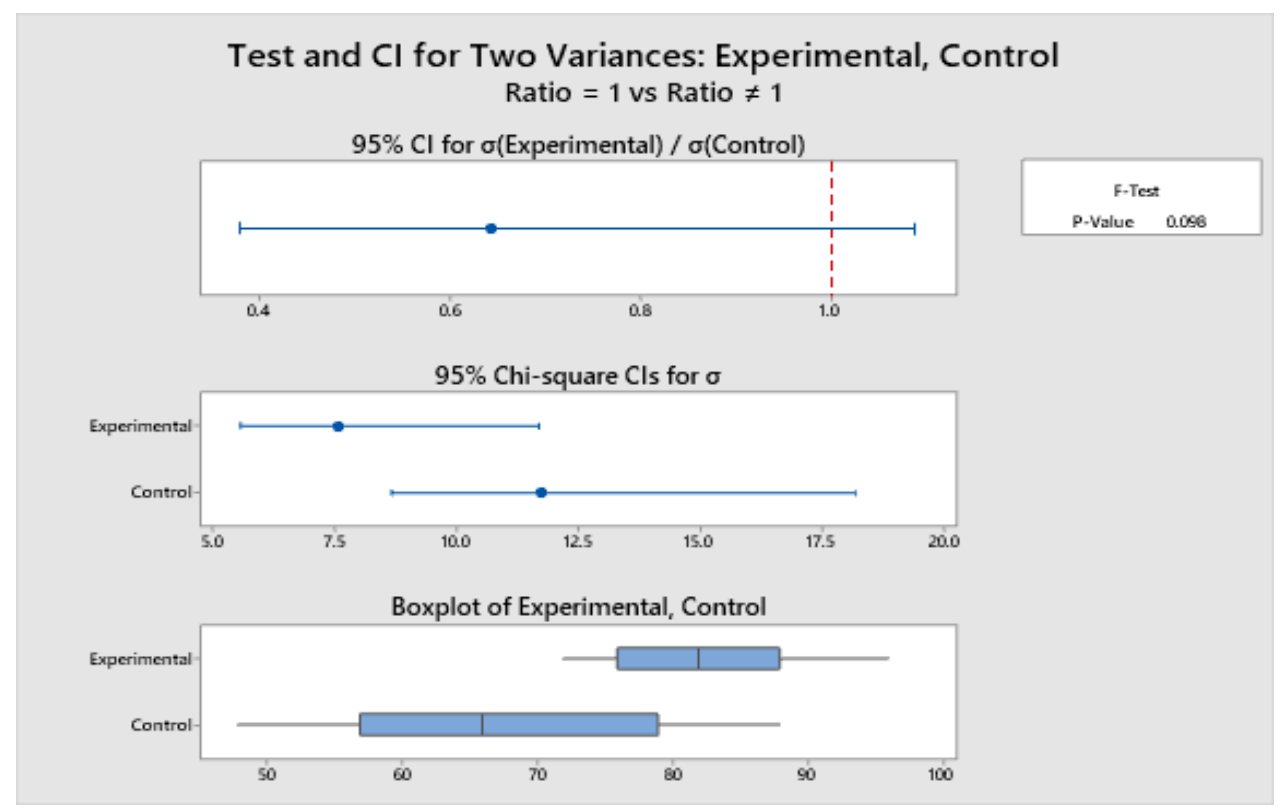

Figure 3. Homogeneity Testing of Eksperimental and Control Class

After confirming that data of both classes were normally distributed and homogenously. A t-test could be done to test the hypothesis.

H1: Pairwork activities technique is effective to be used increating better writing ability of students than conventional technique.

H0: Pairwork activities is not effective to be used in creating better writing ability of students than conventional technique.

The result of t-test obtained that the $\mathrm{P}$-value interpretation is done with the test criteria is reject $\mathrm{H} 0$ or accept $\mathrm{H} 1$ if the $\mathrm{P}$-value $<\alpha$ and vice versa accept $\mathrm{H} 0$ or reject $\mathrm{H} 1$ if the $\mathrm{P}-\mathrm{v}$ alue $>\alpha$, with $\alpha=0.05$.Based on calculations using SPSS, the p-value is $0.00<0.05$. So the p-value obtained is smaller than 0.05 so $\mathrm{H} 0$ is rejected and $\mathrm{H} 1$ is accepted. It means thatthe pairwork activities technique is effective to be used in creating better writing ability of students than the conventional technique.As shown in the following figure.

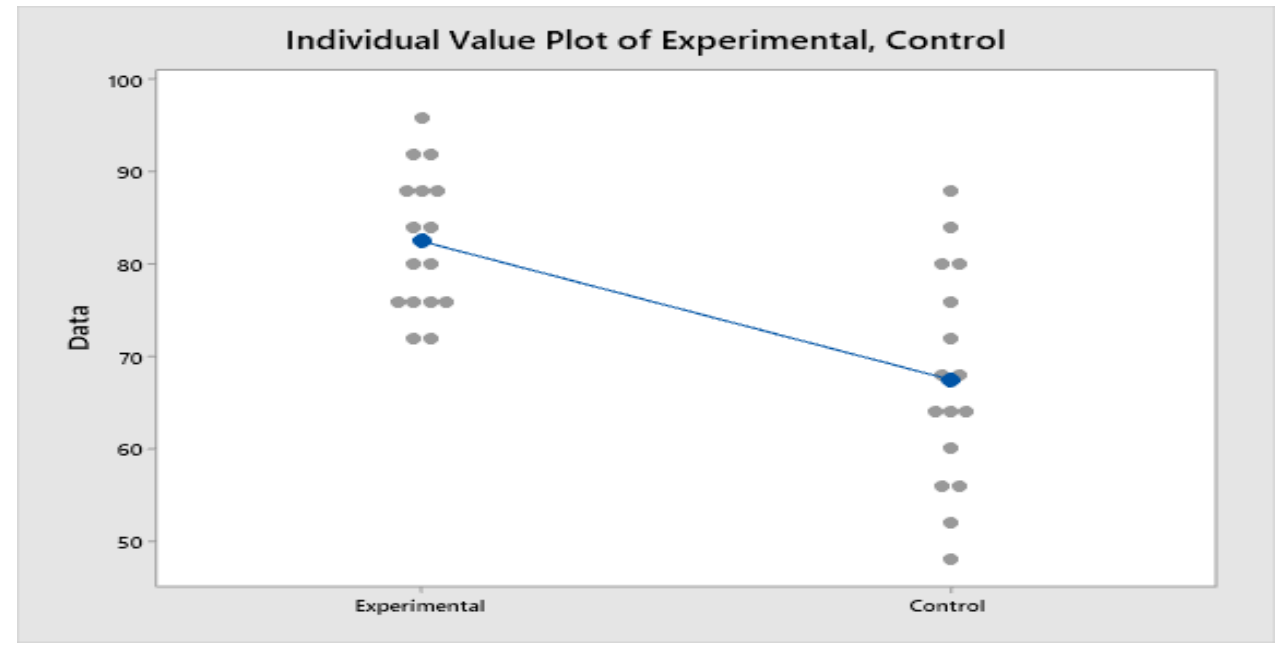

Figure 4. Hypotheses Testing 
The finding shows that the pairwork activities technique effective in creating better student writing ability compared to conventional technique. This is because the application pairwork activities make students more active and engaged in learning because they work both as a couple. They share opinions, do assignments and complete assignments together. When they find difficulties, they ask the teacher. Here, students do not seem bored in learning because they can share their opinions with their partners. They are also seen only asking the teacher occasionally if they find it difficult to work with a partner. Harmer (1998: 207) states that working in pairs increases student participation in language learning. This was seenat each meeting, students participated in making assignments with a partner. They share knowledge with each other.

Sert (2013) conducted research on a comparative analysis between pairwork activities and individual assignments in two classes. The results of his research show that the pairwork technique not only has a positive contribution to learning English but also provides the development of good interpersonal relationships between students in the classroom. While students who are given individual assignments tend to be more individual and do not have good interpersonal relationships with their peers. Therefore, conventional techniques that usually give assignments to students individually do not create better writing ability for students.

\section{CONCLUSION}

The pairwork activities effectively used in creatingbetter writing skills of students with extrovert and introvert than the conventional techniques. This is evidenced by the high mean value of students in the experimental class compared to the control class and also from the results of the first hypothesis test. Application pairwork activities make students more active and engaged with learning because they work both as a couple.Therefore, it is recommended to teachers can apply the technique pairwork activities as a variation in teaching writing.For the next researcher it is also advisable to conduct research on a larger number of samples and also on other English skills such as speaking, reading and listening.

\section{ACKNOWLEDGMENTS}

This study was funded by The Ministry of Research, Technology and Higher Education (Kemenristekdikti) of Indonesia. For that, researchers would like to say thank to Directorate of Research and Society Dedication (DRPM) in the Novice Lecturer Research (PDP) scheme who managed research grants to us. We also thank to all parties who supported and participated in the accomplishment of the research and article.

\section{REFERENCES}

Bercikova Pavlina. (2007). Teacher's role in pairwork. Unpublished Thesis. Masaryk University. 
Brown, H. D. (2004). Language assessment: Principle and classroom practices. Mew York: Pearson Education Inc.

Harmer, J. 1998. The practice of English language teaching. New York : Longman, Inc.

Hedge, T. (2000). Teachingand learning in the language classroom. New York: Cambridge University Press.

Ihsan, R. (2016). The Effect of pairwork technique and students' motivation toward students' speaking skill at second semester of English department students of STAIN Kerinci. Universitas Negeri Padang. Thesis.

McDonough, K. (2004). Learner-learner interaction during pair and small group activities in a Thai EFL context. System, 32(2), 207-224.

Myles, J. (2002). Second language and research: The writing process and error analysis in studens texts. TESL-English Journal, 5(6), 60-78.

Nation, I. S. P. (2009). Teaching ESL/EFL reading and writing. New York and London: Routledge Taylor and Francis Group.

Peha, S. (2004). What is good writing?. New York. Learning Express, LCC.

Sert, O. (2013). Comparative analysis of pairwork and individual assignments in two ELT classes. Journal of Language and Learning, 3(2), 219-232

Suhartono, R. (2013). Upaya peningkatan kualitas pembelajaran membubut mata pelajaran kerja mesin lanjut menggunakan model praktik berpasangan di kelas XII TP A SMK TKM Purworejo tahun pelajaran 2012/2013. Skripsi. Universitas Negeri Yogyakarta.

Zohairy, S. (2014). Effective pairwork strategies to enhance saudi preintermediate college students' language activities. European Scientific Journal, 10(2), 50-63. 